\title{
Growth of feral pigs in New Zealand
}

\author{
Ryszard M. DZIECCIOŁOWSKI, Colin M. H. CLARKE \\ and Brian J. FREDRIC
}

\begin{abstract}
Dzięciołowski R. M., Clarke C. M. H. and Fredric B. J. 1990. Growth of feral pigs in New Zealand. Acta theriol. 35: 77-88.

For 2,674 pigs date and location of kill, sex, field-dressed weight, body length, length, height and condyle height of the mandible were determined. Their age was assessed from (a) tooth replacement and wear and (b) cementum layering in molars. Males were consistently heavier than females from birth onwards, though not significantly so until after aged 1 year. The overall mean weight for males was $41.4 \mathrm{~kg}$, whereas that for females was $29.0 \mathrm{~kg}$. Adult males averaged $60.5 \mathrm{~kg}$, compared to adult females at $41.0 \mathrm{~kg}$. The heaviest pig taken was a 5-year-old male weighing $148.1 \mathrm{~kg}$. Mean weights for males increased consistently until 45 months, after which weights remained relatively stable. Females showed consistent weight increase until 33 months and fluctuated little thereafter. Seasonal weight changes were significant for males $(p<0.001)$, though females showed no significant variation. Overall mean length for males was $121.7 \mathrm{~cm}$, whereas that for females was $111.7 \mathrm{~cm}$. The longest pig was a 4 year old male at $197.3 \mathrm{~cm}$. Males gain in length at a slightly faster rate than females. Males had consistently longer, taller mandibles and taller condyles than females. Feral pigs in New Zealand have body growth rates comparable to wild boar of Europe and feral hogs from USA. All growth variables measured indicated high correlation. Feral pigs exhibited obvious sexual dimorphism with males heavier and longer than females in each age class. Growth is completed at the age of 3-4 years, somewhat later for males than for females.
\end{abstract}

Warsaw Agricultural University, Department of Wildlife Management, Rakowiecka 26/30, 02-528 Warsaw, Poland (RMD); Forest Research Institute, P.O.Box 31-011, Christchurch, New Zealand (CMHC, BJF).

Key words: growth, body, mandible, Sus scrofa, New Zealand

\section{Introduction}

Feral pigs Sus scrofa L., 1758 are an important recreational hunting resource in New Zealand. Annual harvest for the northern South Island only $\left(65,560 \mathrm{~km}^{2}\right)$ is estimated at 20,000-25,000 (C. M. H. Clarke and R. M. Dzięciołowski, unpubl.), and the national harvest appears likely to exceed 100,000 animals. Despite the abundance of feral pigs in New Zealand, their biology is poorly documented. Knowledge of body weight and length, as well as jaw size, in relation to animal age, sex, and season of the year, are important for a wider understanding of the species biology. The aim of this paper is to describe patterns of physical growth in feral pigs, and in particular identify differences arising from age, sex, and season. Acquisition of these data were aimed at more informed management of the feral pig resource.

This study is part of a wider study of the biology and harvest capacity of feral pigs from throughout the northern half of the South Island. Previous papers have described the sex and age structures of the population (Dzięciołowski and Clarke 1989) and the effects of recreational hunting on the resource (Clarke 1989). 


\section{Methods}

Data on 2,674 autopsied pigs were collected between July 1986 and October 1987 and included date and location of kill, sex, field-dressed weight (gutted, heart, lungs, head and hocks attached), and body length (measured from tip of snout to base of tail). Pigs were aged using both tooth replacement and tooth wear for juveniles, and dental cementum for adults (Hayashi et al. 1977). Skeletal growth was determined from the length, height, and condyle height of the mandible (Fig. 1). Whole pig growth was subsequently determined from dressed body weight, body length, and weight/length ratios. Not all measurements were recorded for each animal.

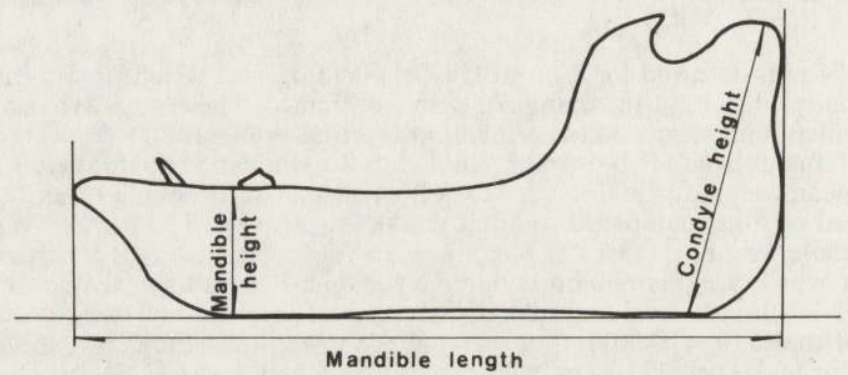

Fig. I. Jaw measurements.

All data were analysed using the SAS computer package (SAS, 1985). Analyses and statistical methods used included analysis of variance, calculation of mean and $95 \%$ uncertainty limits (Andrews et al. 1980), multiple comparison (Duncan's Multiple Range Test and Least Significant Difference), and regression analysis. When the raw data deviated significantly from normality, parametric analyses used transformed

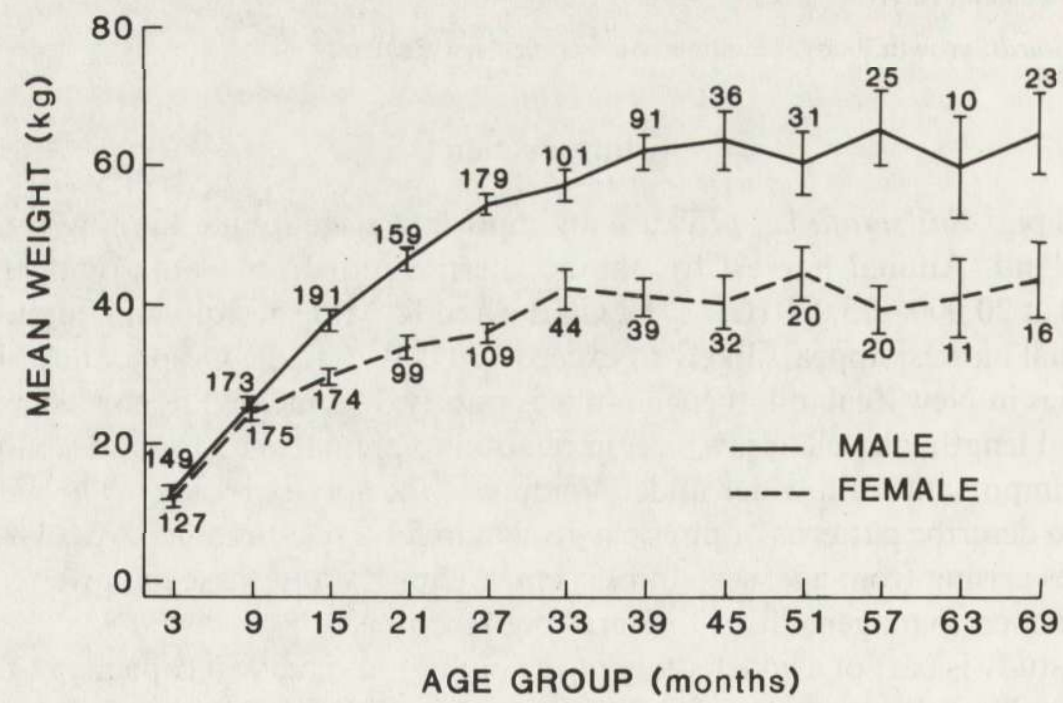

Fig. 2. Mean pig dressed weight by age group and sex with $95 \%$ uncertainty limits. Sample size are included. Mid-points of age groups are shown. Older age groups were omitted because of low sample sizes. 
data and all graphs and tables of means were back-transformed to the original scale.

When growth variables were regressed against age, actual ages in months rather than age group were used (Dzięciołowski and Clarke 1989). Monthly and seasonal variation in weights were examined using animals older than 24 months.

\section{Results \\ Body weight}

Pig dressed weights varied significantly by sex $\left(F_{1,2038}=547.83, p<0.001\right)$ and age group (as defined in Dzięciołowski and Clarke 1989) $\left(F_{21,2038}=148.56, p<0.001\right)$. There was also a significant sex variation within the age structures $\left(F_{17,2038}=9.17\right.$, $p<0.001$ ) (Fig. 2).

Males were consistently heavier than females from birth onwards, though not significantly so until after aged 1 year. The overall mean weight for males was $41.4 \mathrm{~kg}$, whereas the overall mean weight for females was $29.0 \mathrm{~kg}, 25 \%$ lighter. Adult males averaged $60.5 \mathrm{~kg}$, compared to adult females at $41.0 \mathrm{~kg}$. The heaviest pig taken was a 5-year-old male weighing $148.1 \mathrm{~kg}$ (Fig. 3). Males also gain weight at a slightly faster rate than females, i.e.

$$
\begin{aligned}
\text { weight males } & =5.0 \times \text { age }^{0.68} R^{2}=0.6973 ; \\
\text { weight females } & =6.30 \times \text { age }^{0.51} R^{2}=0.5560 .
\end{aligned}
$$

The fitted equations may be steeper than in reality because of insufficient numbers of pigs taken older than 6 years ( 72 months) compared to pigs taken younger than 6 years.

Males reach $50 \%$ of their adult weight at $12-15$ months and about $75 \%$ of their adult weight by 21 months. Mean weights for males increased consistently until 45 months, after which weights remained relatively stable (Fig. 2). By comparison, females attained $50 \%$ of their adult body weight at 9 months and $75 \%$ of their adult weight by 15 months. Females showed consistent weight increase until 33 months and fluctuated little thereafter.

Monthly variations in weight differed significantly $\left(F_{11,806}=341.92, p<0.001\right)$ with both males and females in April - May being significantly heavier than in August - September (Fig. 4). A decrease in mean weight by females in March, was reflected by a similar weight loss by males in February. On regrouping the months into seasons, seasonal weight changes were significant for males $\left(F_{3,511}=5.52, p<0.001\right)$, though females showed no significant variation. Males reach peak weight in autumn, lose it during winter-spring, and then start gaining weight during summer. Females show a similar pattern to males, though with less seasonal fluctuation and a peak spread over autumn and winter. Regrouping of data into seasons smoothed a lot of the monthly variation (Fig. 5).

\section{Body length}

Pig length varied significantly by $\operatorname{sex}\left(F_{1,1622}=23.05, p<0.001\right)$ and age group $\left(F_{21,1622}=90.86, p<0,001\right)$ and also varied significantly by sex within age structures 

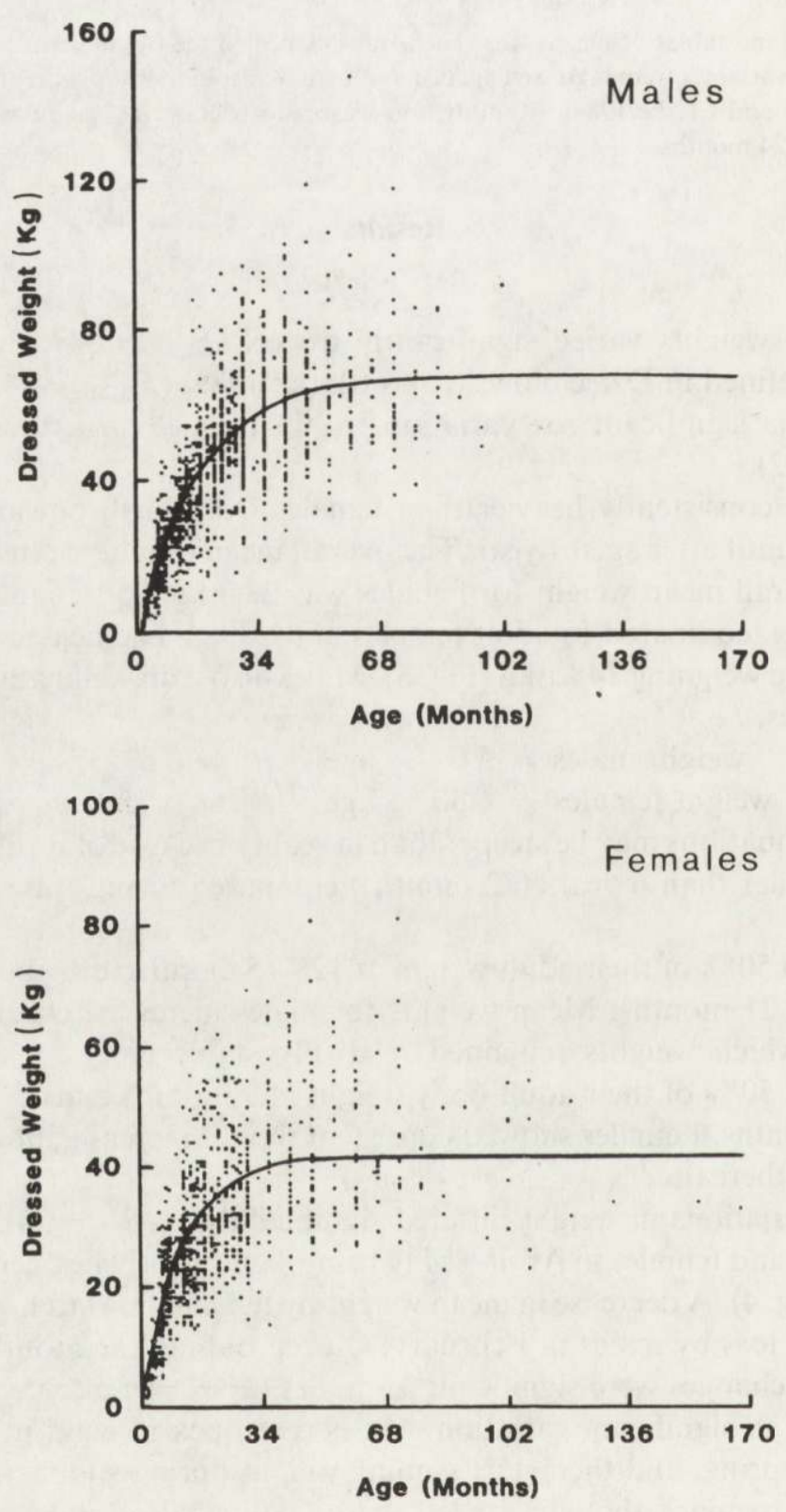

Fig. 3. Growth curve for pig dressed weight.

$\left(F_{17,1622}=2.47, p<0.001\right)$ (Fig. 6), with males being consistently longer than females. Overall mean length for males was $121.7 \mathrm{~cm}$, whereas that for females was $111.7 \mathrm{~cm}$, $8.2 \%$ shorter. The longest pig was a 4-year-old male at $197.3 \mathrm{~cm}$. Regression analysis of female and male length and age data gave the following equations: 


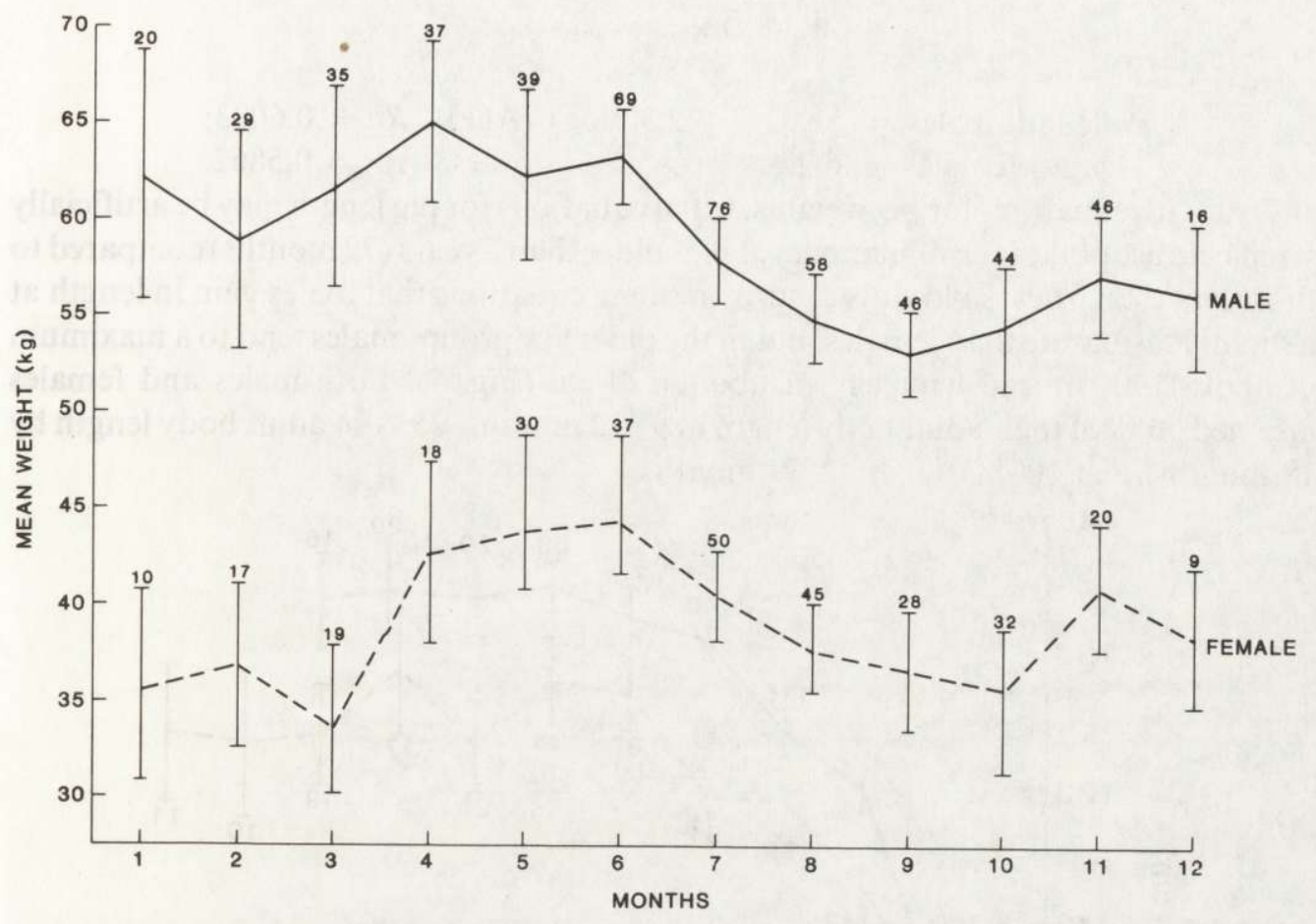

Fig. 4. Mean monthly dressed weight of pigs with $95 \%$ uncertainty limits. Sample sice are included.

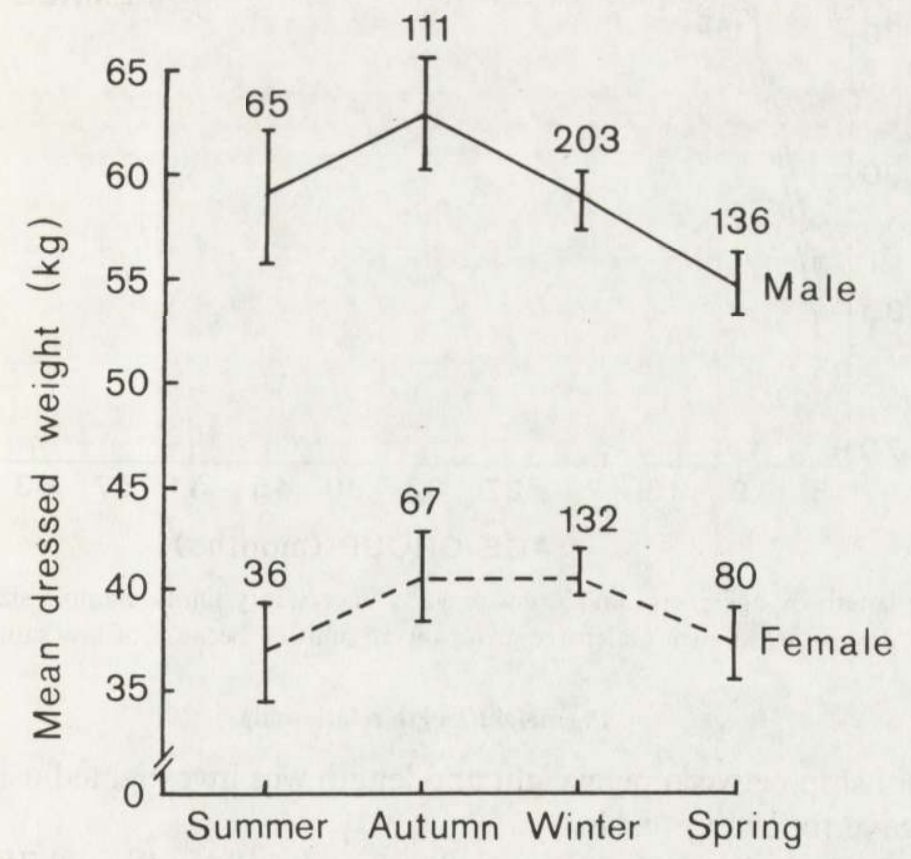

Fig. 5. Mean seasonal dressed weight of pigs with $95 \%$ uncertainty limits. Sample sizes are included. 


$$
\begin{aligned}
\text { length males } & =51.62+22.30 \log _{\mathrm{e}}(\text { Age }) & R^{2}=0.6083 \\
\text { length females } & =6.22 \times \mathrm{Age}^{0.20} & R^{2}=0.5862
\end{aligned}
$$

As with equations for pig weights, fitted equations for pig length may be artificially steep because of the lack of numbers of pigs older than 6 years ( 72 months) compared to those less than 6 years old. It is clear from these equations that males gain in length at a slightly faster rate than females, but in the older age groups males tend to a maximum of about $130 \mathrm{~cm}$ and females - of about $120 \mathrm{~cm}$ (Fig. 7). Both males and females attained $50 \%$ of their adult body length at $9-12$ months, $75 \%$ of adult body length by 18 months, and $100 \%$ by about 39 months.

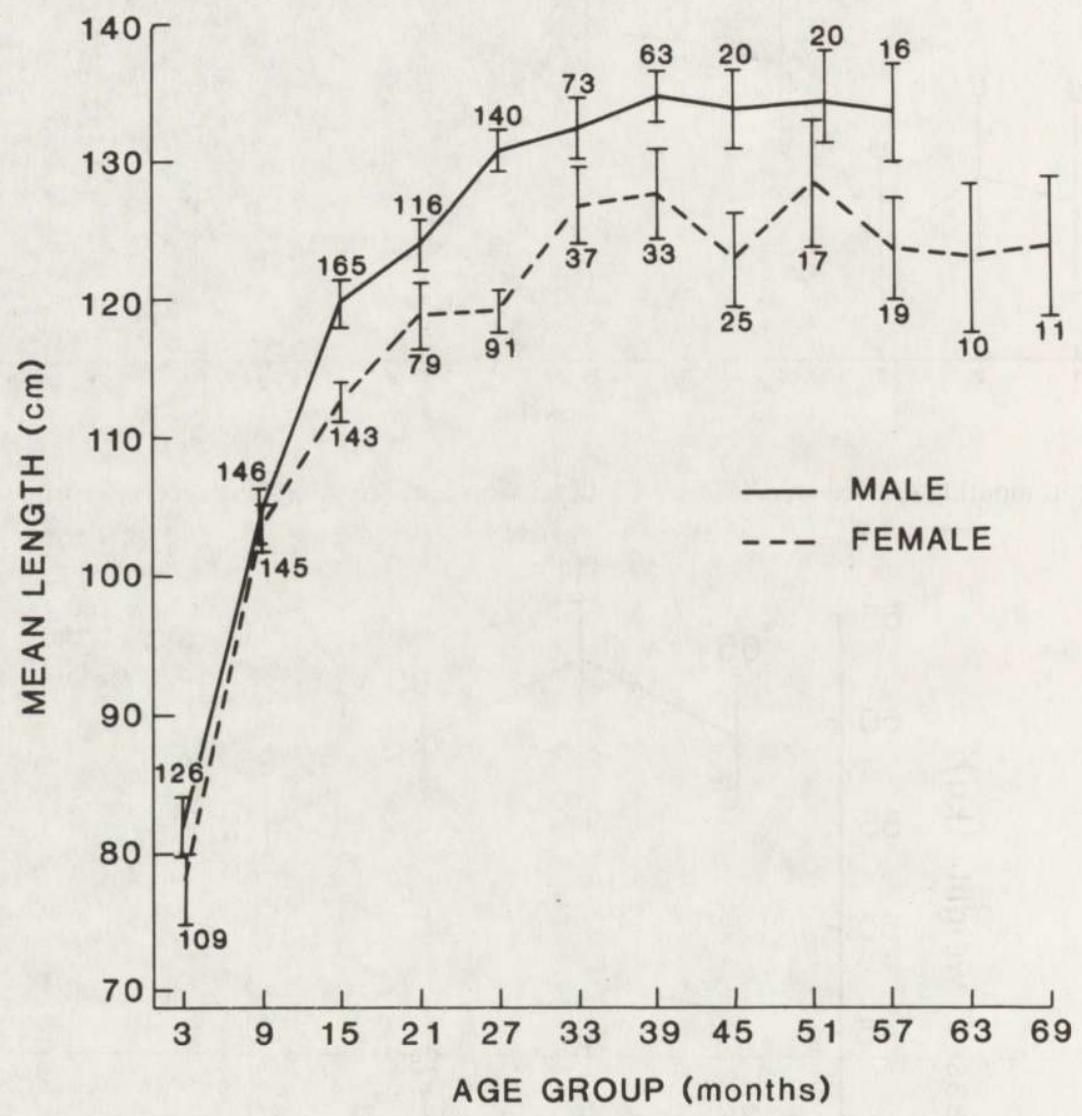

Fig. 6. Mean pig length by age group and sex with $95 \%$ uncertainty limits. Sample sizes are included. Mid-point of age groups are shown. Older age groups were omitted because of low sample sizes.

\section{Pig weight/length relationship}

The relationship between pig weight and length was investigated using regression analysis and gave following results:

$$
\begin{aligned}
\text { weight males }=1.989 \times \text { exp. }(0.025 \times \text { length }) & R^{2}=0.7586 \\
\text { weight females }=1.953 \times \text { exp. }(0.024 \times \text { length }) & R^{2}=0.7106
\end{aligned}
$$



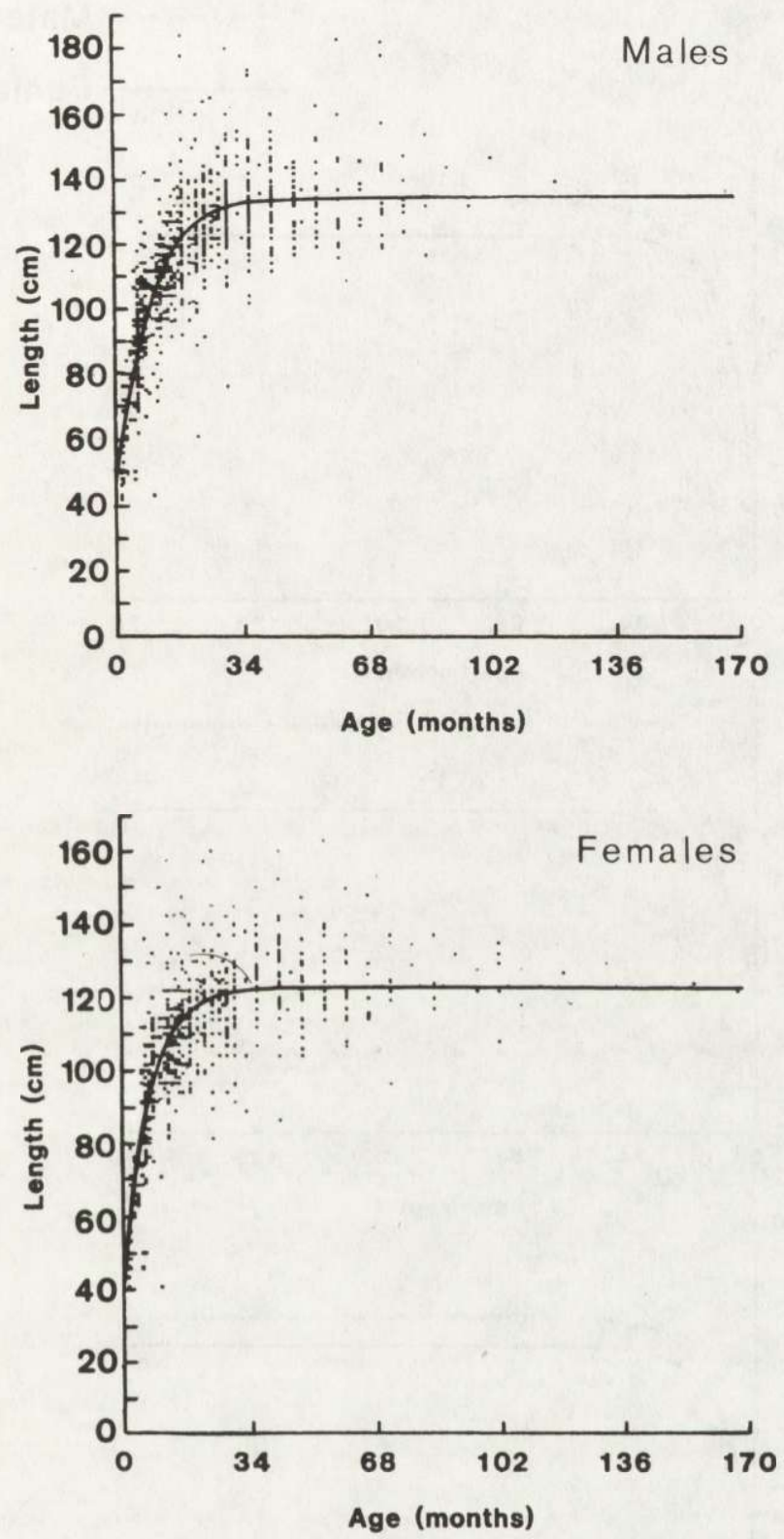

Fig. 7. Growth curve for pig length.

These equations show that weight/length relationships of males and females are similar. The weight/length data for males was more variable than that for females, especially for the larger animals. 
.......... Males
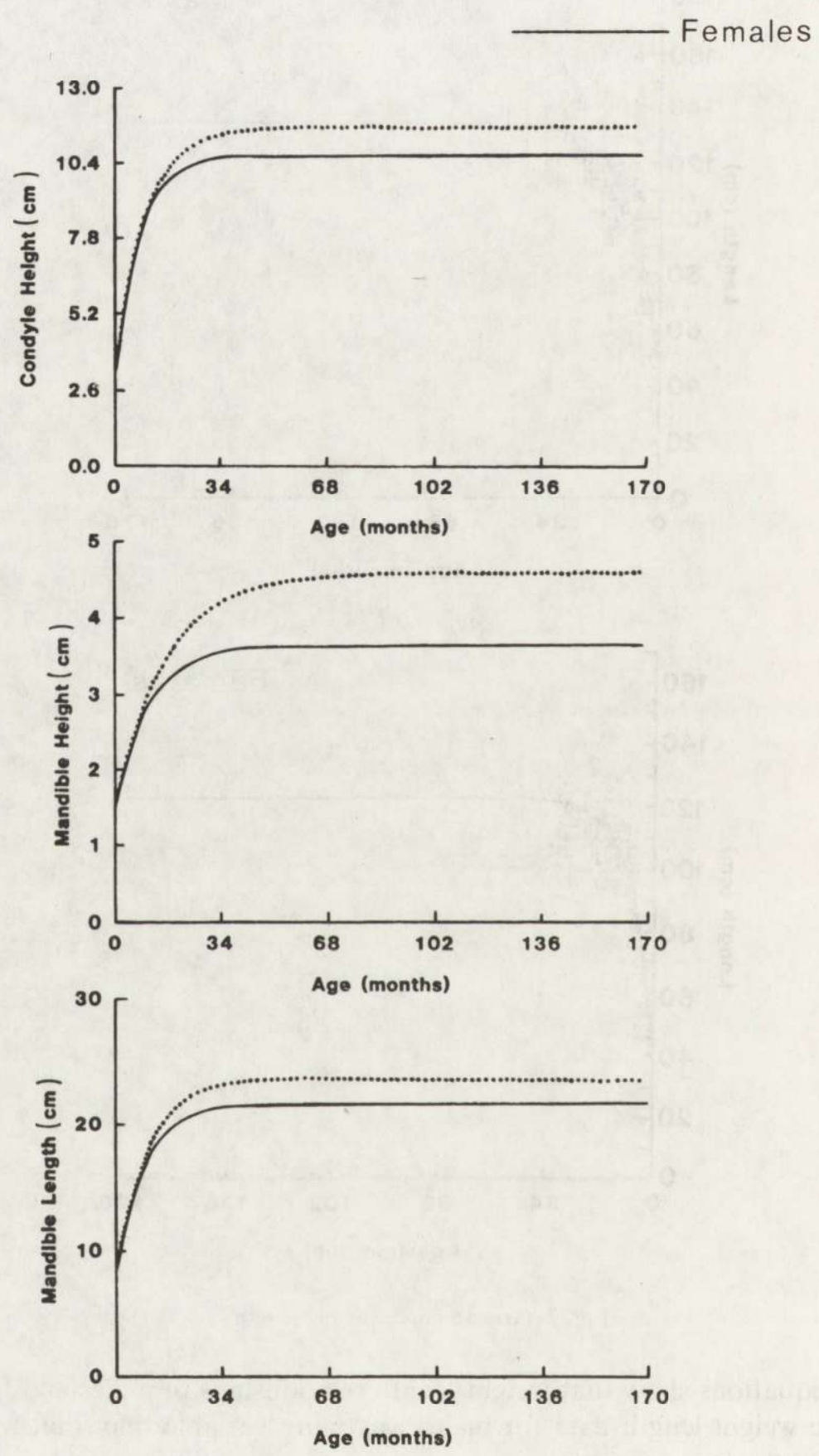

Fig. 8. Growth curves for pig mandibles. 


\section{Jaw measurements}

All mandible growth measurements (length, height, and condyle height) varied significantly by sex and age group, and also within age groupings ( $p<0.001$, Table 1$)$. Males had consistently longer, taller mandibles and taller condyles than females (Fig. 8 ) and on average, were $8-13 \%$ larger than those of females.

Table 1. Variation in jaw size with age and $\operatorname{sex}\left({ }^{* *} p<0.001\right)$.

\begin{tabular}{|c|c|c|c|c|c|c|}
\hline \multirow{2}{*}{ Source } & \multicolumn{2}{|c|}{ Mandible length } & \multicolumn{2}{|c|}{ Mandible height } & \multicolumn{2}{|c|}{ Condyle height } \\
\hline & $D F$ & $F$ & $D F$ & $F$ & $D F$ & $F$ \\
\hline $\begin{array}{l}\text { Sex } \\
\text { Age } \\
\text { Sex/Age group } \\
\text { Error } \\
n\end{array}$ & $\begin{array}{r}1 \\
20 \\
17 \\
1852 \\
1890 \\
\end{array}$ & $\begin{array}{r}65.8^{* *} \\
339.4^{* *} \\
7.7^{* *}\end{array}$ & $\begin{array}{r}1 \\
21 \\
17 \\
2067 \\
2106\end{array}$ & $\begin{array}{c}18.0^{* *} \\
33.6^{* *} \\
1.9^{* *}\end{array}$ & $\begin{array}{r}1 \\
20 \\
17 \\
1834 \\
1872 \\
\end{array}$ & $\begin{array}{r}44.8^{* *} \\
261.1^{* *} \\
6.2^{* *}\end{array}$ \\
\hline
\end{tabular}

Table 2. Corelation coefficients between jaw measurements and other growth indices $(p<0.01)$.

\begin{tabular}{lccc}
\hline & \multicolumn{2}{c}{ Mandibular } & Condyle \\
\cline { 2 - 3 } & length & height & height \\
\hline Mandibular length & 1.0 & 0.9329 & 0.9534 \\
Mandibular height & 0.9329 & 1.0 & 0.8952 \\
Condyle height & 0.9534 & 0.8952 & 1.0 \\
Body weight & 0.8349 & 0.8328 & 0.8041 \\
Log (weight) & $(0.9065)$ & $(0.8489)$ & $(0.8932)$ \\
Body length & 0.8646 & 0.8084 & 0.8515 \\
Age & 0.6805 & 0.6795 & 0.6644 \\
Log (age) & $(0.8872)$ & $(0.8323)$ & $(0.8852)$ \\
\hline & Males only & & \\
Mandibular length & 1.0 & 0.9336 & 0.9542 \\
Mandibular height & 0.9336 & 1.0 & 0.9088 \\
Condyle height & 0.9542 & 0.9088 & 1.0 \\
Body weight & 0.8603 & 0.8489 & 0.8378 \\
Log (weight) & $(0.9196)$ & $(0.8613)$ & $(0.9078)$ \\
Body length & 0.8612 & 0.8160 & 0.8456 \\
Age (and & 0.7359 & 0.7831 & 0.7240 \\
Log (age) & $(0.9080)$ & $(0.8889)$ & $(0.9037)$ \\
\hline & Females only & & \\
Mandibular length & 1.0 & 0.9354 & 0.9505 \\
Mandibular height & 0.9354 & 1.0 & 0.9982 \\
Condyle height & 0.9505 & 0.8892 & 1.0 \\
Body weight & 0.7711 & 0.7329 & 0.7484 \\
Log (weight) & $(0.8730)$ & $(0.8132)$ & $(0.8630)$ \\
Body length & 0.8598 & 0.7961 & 0.8500 \\
Age (age) & 0.6629 & 0.6481 & 0.6258 \\
Log (age) & $(0.9000)$ & $(0.8475)$ & $(0.8820)$ \\
\hline & & & \\
\hline
\end{tabular}

All mandible measurements for males increased consistently until 39 months (Fig. 8). Males attained $50 \%$ of adult mandible length by 9 months and $75 \%$ by 15 months. Growth of mandible height and condyle height was slower and the 50 and $75 \%$ levels 
attained at 15 and 21 months respectively.

Mandible measurements for females increased consistently until 33 months. Females attained $50 \%$ of adult mandible growth by 9 months and $75 \%$ of adult mandible length and condyle height by 21 months. The $75 \%$ level of adult mandible height was attained at 24-25 months. Overall, these results suggest that mandible growth for females occurs earlier than that of males, and ceases up to 18 months earlier. Mandible height for males was significantly larger than that for females throughout their lives.

\section{Correlation of jaw measurements}

All jaw measurements were highly correlated with each other both overall and within the sexes (Table 3). The other growth variables were also correlated with jaw measurements and the relationship with weight and age were improved by taking the logarithm of the variable (i.e., a curvilinear relationship).

\section{Discussion}

Sample sizes used in this study varied from 1662 to 2674 , depending upon the character measured. Harvesting of pigs was intensive and, together with the high productivity of the species, resulted in a sample biased towards juveniles. Although this contributed to some distortion of the fitted equations, it did not alter the overall patterns.

Analysis of weights and lengths reveal that the physical growth of feral pigs is completed when animals are 3-4 years old, and later in males than in females. Feral pigs reach $50 \%$ of their adult weight at $9-12$ months and about $75 \%$ of their adult weight by $15-21$ months (Fig. 2). Although the weight of males within an age group was variable, some males older than 5 years had greater weights than males in the 3-5 year group. This appears to result from a change in body form as older males develop heavy shields (cartilaginous padding across shoulders) and the neck and head region thickened with muscle and cartilaginous tissue. Larger size for males has obvious social advantages, as evidenced from the extent of woundings and scar tissue on adult boars. Despite the presence of large old males, the majority of pigs (males and females) appeared "past their prime" by the age of 6 years, probably because of tooth wear and loss and damage to tusks which would have affected their feeding (C. M. H. Clarke and R. M. Dzięciołowski, unpubl.). Except for old and diseased pigs, most were in good condition. Accordingly, maximum weights probably approximate the limits for feral pigs in this area.

The generally advanced state of growth of young females compared to young males appears associated with minimum body size requirements for sexual maturity (at 5 months in some animals, R. M. Dzięciołowski and C. M. H. Clarke, unpubl.). Because of early and frequent breeding of females, energy is diverted into reproduction rather than into further growth, and male growth increases relative to that of females 
between 9 and 15 months. Skeletal growth in both sexes occurs at the expense of soft body tissue as elongation occurred over a similar 39 month period. All other growth variables were attenuated for males with slight but consistent body weight and mandible growth continuing on average 16 months longer than for females.

Average carcass weight of New Zealand feral pigs does not deviate much from that of wild boars from Europe and hybrids from USA (Table 3). Wild boars from Lithuania (Janulaitis 1988) are obviously heaviest among those compared. Similarly, average body lengths of pigs in New Zealand were again comparable with wild boar populations, at least those from East Germany (Table 4). Again, wild boars from Lithuania were longer than those from East Germany and feral pigs from New Zealand.

Table 3. Comparison of feral pig dressed weights (in $\mathrm{kg}$ ) with those of wild boars from Europe and North America. Note in Methods the definition of field dressed weight as used in this study. In Europe field-dressed weight means that heart and lungs are removed along with gut viscera.

\begin{tabular}{|c|c|c|c|c|c|c|c|c|c|}
\hline \multirow{3}{*}{ Country } & \multicolumn{8}{|c|}{ Age } & \multirow{3}{*}{ Source } \\
\hline & \multicolumn{2}{|c|}{ Piglets } & \multicolumn{2}{|c|}{ Yearlings } & \multicolumn{2}{|c|}{$\begin{array}{c}\text { Females } \\
>2 \text { yrs old }\end{array}$} & \multicolumn{2}{|c|}{$\begin{aligned} & \text { Males } \\
> & 2 \text { yrs old }\end{aligned}$} & \\
\hline & $\overline{\mathrm{x}}$ & $\mathrm{n}$ & $\bar{x}$ & $\mathrm{n}$ & $\overline{\mathrm{x}}$ & $\mathrm{n}$ & $\bar{x}$ & $\mathrm{n}$ & \\
\hline $\begin{array}{l}\text { Hybrid wild boar } \\
\text { from USA }\end{array}$ & 18.4 & 172 & 41.3 & 142 & 50.2 & 155 & 59.4 & 112 & Henry 1970 \\
\hline $\begin{array}{l}\text { Feral pig from } \\
\text { New Zealand }\end{array}$ & 18.5 & 624 & 37.5 & 623 & 39.6 & 315 & 64.3 & 526 & this study \\
\hline $\begin{array}{l}\text { Wild boar: } \\
\text { East Germany }\end{array}$ & 22.6 & 196 & 45.6 & 276 & 61.1 & 58 & 72.1 & 101 & Briedermann 1970 \\
\hline Poland & 23.7 & 370 & 37.9 & 1094 & 59.0 & 493 & 65.5 & 1101 & $\begin{array}{l}\text { Miłkowski } \\
\text { and Wójcik } 1984\end{array}$ \\
\hline Lithuania & 29.0 & 52 & 58.3 & 30 & 83.9 & 39 & 96.9 & 57 & Janulaitis 1988 \\
\hline
\end{tabular}

Table 4. Comparison of feral pig total lengths (in $\mathrm{cm}$ ) with those of wild boars from Europe.

\begin{tabular}{|c|c|c|c|c|c|c|c|c|c|}
\hline \multirow{3}{*}{ Country } & \multicolumn{8}{|c|}{ Age } & \multirow{3}{*}{ Source } \\
\hline & \multicolumn{2}{|c|}{ Piglets } & \multicolumn{2}{|c|}{ Yearlings } & \multicolumn{2}{|c|}{$\begin{array}{c}\text { Females } \\
>2 \text { yrs old }\end{array}$} & \multicolumn{2}{|c|}{$\begin{array}{c}\text { Males } \\
>2 \text { yrs old }\end{array}$} & \\
\hline & $\bar{x}$ & $\mathrm{n}$ & $\bar{x}$ & $\mathrm{n}$ & $\bar{x}$ & $\mathrm{n}$ & $\bar{x}$ & $\mathrm{n}$ & \\
\hline $\begin{array}{l}\text { Feral pig from } \\
\text { New Zealand }\end{array}$ & 92 & 526 & 119 & 503 & 125 & 264 & 137 & 369 & this study \\
\hline $\begin{array}{l}\text { Wild boar: } \\
\text { East Germany }\end{array}$ & 100 & 196 & 126 & 285 & 136 & 60 & 143 & 104 & Briedermann 1970 \\
\hline Lithuania & 29.0 & 52 & 58.3 & 30 & 83.9 & 39 & 96.9 & 57 & Janulaitis 1988 \\
\hline
\end{tabular}

Physical growth in New Zealand pigs also occurs over an equivalent period (3-4 years) to that found by Briedermann (1970) for wild boars in central Europe, and by Barrett (1978) for feral hogs in California. The Lithuanian wild boar however, completes its body growth at the age of about 5 years (females) and 6-7 years (males), 
(Janulaitis 1988).

High correlation between weight and length found in our material was also noted by Brisbin et al. (1977) for feral hogs in south-eastern USA and by Janulaitis (1988) for wild boar in north-eastern Europe. Contrary to Brisbin et al. findings, however, both we and Janulaitis (1988) found an obvious sexual dimorphism in all growth variables measured.

\section{Conclusions}

Feral pigs in New Zealand have body growth rates comparable to wild boar of Europe and feral hogs from USA. All growth variables measured indicated high correlation. Feral pigs exhibited obvious sexual dimorphism with males heavier and longer than females in each age class. Growth is completed at the age of 3-4 years, but somewhat later for males than for females.

Acknowledgements: We wish to thank hunters, game buyers, and New Zealand Government Departmental staff who assisted in the collection of data. Dr J. Coleman kindly commented on an earlier draft. Authors thank Dr I. L. Brisbin, Jr for his inspiring review of the paper.

\section{References}

Andrews H. P., Snee R. D. and Garner M. H. 1980. Graphical display of means. Statistician 34: 195-199. Barrett R. H. 1978. The feral hog on the Dye Creek Ranch, California. Hilgardia 46: 283-345.

Briedermann L. 1970. Zum Körper- und Organwachstum des Wildschweines in der Deutschen Demokratischen Republik. Arch. Forstwes. 19: 401-420.

Brisbin I. L., Jr, Geiger R. A., Graves H. B., Pinder J. E. III, Sweeney J. M. and Sweeney J. R. 1977. Morphological characterizations of two populations of feral swine. Acta theriol. 4: 75-85.

Clarke C. M. H. 1989. Can hunters control feral pigs? Proceedings "Seminar 2000", NZ Deerstalkers' Association, Wellington.

Dzięciołowski R. and Clarke C. M. H. 1989. Age structure and sex ratio in feral pig population. Acta theriol. 34: $525-536$.

Hayashi Y., Nishida T. and Mochizuki K. 1977. Sex and age determination of the Japanese wild boar (Sus scrofa leucomystax) by the lower teeth. Jap. J. vet. Sci. 39: 165-174.

Henry V. G. 1970. Weights and body measurements of European wild hogs in Tennessee. Journal of the Tennessee Academy of Science 45: 20-23.

Janulaitis Z. 1988. Opredelenie massi tela kabana po eksteriternim priznakam. [In: Teriologičeskie issledovanija v Litvie.]. Vilnius: 44-53.

Miłkowski L. and Wójcik J. M. 1984. Structure of wild boar harvest in the Białowieża Primeaval Forest. Acta theriol. 29: 337-347.

SAS Institute Inc. 1985. SAS Users' Guide: Statistics, Version 5 Edition. SAS Institute Inc., Cary, NC: $1-956$.

Received 14 July 1989, accepted 17 October 1989. 